DOI 10.18551/rjoas.2020-11.32

\title{
THE INFLUENCE OF INFORMATION ACCESS AND SOCIAL MOTIVES ON YOUTH PARTICIPATION IN THE DEVELOPMENT OF EDUCATIONAL TOURISM IN KEDIRI REGENCY, INDONESIA
}

\author{
Mukti Tri ${ }^{\star}$, Anantanyu Sapja, Mulyanto \\ Department of Postgraduate Extension Education, Sebelas Maret University, Indonesia \\ *E-mail: triimuktiy@gmail.com
}

\begin{abstract}
Kediri Regency is a tourist destination city that is included in the territory of East Java Province, there are various types of tourist attractions in Kediri Regency, educational tourism is one that is being developed in several districts, namely honey pumpkin educational tours, honey educational tours and guava educational tours. This research is aimed at determining the influence of information access and youth social motives in the development of educational tourism in Kediri Regency which makes youth participation requirements. It was a quantitative study using SPSS for windows. The population in this research was young people aged 16-30 years with a total sample of 120 youths spread over 3 districts in Kediri Regency. The results indicate that $t$ count $>t$ table $(5.089>1.657)$ means that information access has a significant influence on youth participation in developing educational tourism in Kediri district and there is a significant influence between social motives (achievement, avoiding conflict) on youth participation as evidenced by $t$ count $>t$ table $(3,311>1,657)$. The results of the $F$ test show a significant value $(0.000)<$ of $(0.05)$ meaning that simultaneously access to information and social motives have a significant influence on youth participation in developing educational tourism in Kediri district.
\end{abstract}

\section{KEYWORDS}

Information access, social motives, youth, participation, educational tourism.

Tourism can be defined as activities, services and industrial products capable of creating travel experiences for tourists (Mulyadi, 2009). Based on the development policy in the Tourism Development Master Plan of East Java, Kediri Regency is in area C which focuses on coastal tourism, cultural tourism, artificial tourism, educational tourism and nature tourism (Seodarso, et al, 2014).

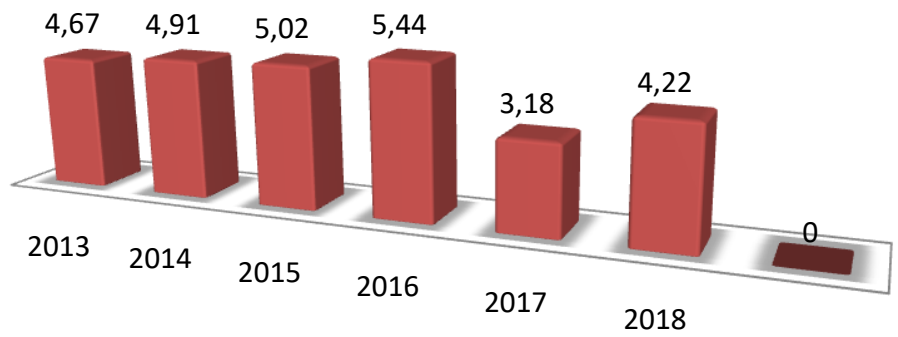

Figure 1 - Unemployment, \% (Source: Badan Pusat Statistik (Central Bureau of Statistics, 2019)

In 2017, there were 1,718,987 tourists visited Kediri Regency and ranked Kediri Regency 9th out of 38 on the list of the most visitors in East Java. Kediri Regency is a tourist city that is included in the area of East Java Province, there are various types of tourist attractions in Kediri Regency, one of which is educational tourism that is developing in several sub-districts, namely honey pumpkin education tourism, honey education tourism and guava education tourism. Educational tourism or more popularly known as edutourism is a tourism program where tourists visit a tourist attraction with the main purpose of obtaining a direct learning experience from these tourism objects. 
The phenomenon of migration carried out by youth makes educational tourism slow even though the existence of educational tourism is a very potential opportunity to be developed will be able to reduce unemployment. The East Java Migration Agency recorded 10,445 youths migrating out of Kediri Regency, among them aiming to get jobs (BPS, 2015).

The amount of potential that exists is balanced with the high interest of young people to migrate to be an interesting phenomenon to study, how the influence of information access and youth social motives in the development of educational tourism in Kediri Regency makes youth participation requirements.

\section{METHODS OF RESEARCH}

This research uses a quantitative approach aimed at testing relationships between variables, testing theories to predict a symptom with statistical methods. According to Saptutyningsih, et al (2019) quantitative methods are the development of mathematical models, theory testing, hypothesis testing and showing the relationship between variables. This research used a survey method using a questionnaire that contained a number of questions related to the research variables and then conducted interviews with the sample in the research. The research sample of 120 people was selected using a proportional sampling technique, which is a technique used in heterogeneous population elements and has proportional levels. The sample will be representative if the sample number is $10 \%$ of the population. The population was youth who lived in Bringin village, Toyoresmi village and Jambu village aged $16-30$ years with a total of 1,200 youth. Furthermore, sampling is done by means of simple random sampling (simple random sampling technique) by drawing. The research was conducted in three sub-districts that are in the process of developing educational tourism.

Table 1 - Location description of educational tourism research in Kediri Regency

\begin{tabular}{|l|l|l|}
\hline \multicolumn{1}{|c|}{ Districts } & \multicolumn{1}{c|}{ Type of Tourism } & \multicolumn{1}{c|}{ Location of Tourism } \\
\hline Keyen kidul & Guava educational tour & Jambu Village \\
\hline Ngasem & Honey pumpkin educational tour & Toyoresmi Village \\
\hline Badas & Honey educational tour & Bringin Village \\
\hline
\end{tabular}

The analysis used to determine the influence of information access and social motives on youth participation in the development of educational tourism in Kediri was carried out using multiple regression analysis using SPSS for windows to determine the determinant coefficient, $T$ test and $F$ test. The meaning of information access in this research is the communication that exists between educational tourism managers and local youth, while the social motive is the encouragement of youth to gain recognition of social status in society and encouragement of youth to avoid social sanctions.

\section{RESULTS AND DISCUSSIONS}

Multiple linear regression is used to determine the influence of two or more independent variables with one dependent variable. In this research, regression analysis was used to analyze the influence of information access (X1) and social motives (X2) on youth participation ( $\mathrm{Y}$ ) in the development of educational tourism in Kediri Regency.

Based on the analysis results, the regression equation is obtained as follows:

$$
Y=-3,894+1,008 X 1+0,438 X 2
$$

Based on the results of the above analysis, the results of the regression coefficient can be interpreted as follows:

- The constant value $(\alpha)=-3,894$ can be interpreted that if access to information and social motives is considered constant or does not change, youth participation is 3,894 . The meaning of the constant of -3.894 is a negative influence. A negative 
constant means that there is a decrease in youth participation which is caused by decreased information received by youth and low social motives.

- The regression coefficient for the information access variable is 1.008 , meaning that if access to information increases by one percent, participation will increase by 1.008 units, assuming other independent variables are of fixed value.

- The regression coefficient for the social motive variable is 0.438 , meaning that if the social motive increases by one percent, the participation will increase by 0.438 units, assuming the other independent variables have a fixed value.

Table 2 - The Results of Multiple Linear Regression Analysis

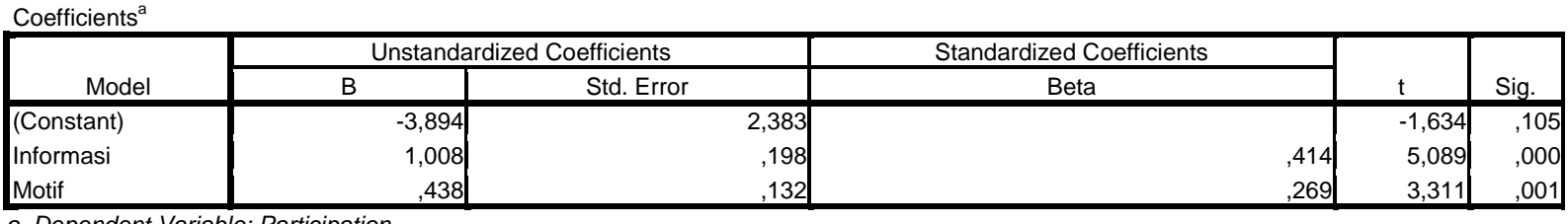

a. Dependent Variable: Participation.

Source Primary data was processed, 2020

The $t$ test was used to partially determine the influence of information access and social motives on youth participation in the development of educational tourism in Kediri Regency. The steps in the t test are as follows:

Determining the Hypothesis:

- Ho: Information access partially does not affect youth participation in the development of educational tourism in Kediri Regency;

- Ha: Social motives partially affect youth participation in the development of educational tourism in Kediri Regency.

Determining $\mathrm{t}$ count and $\mathrm{t}$ table: $\mathrm{T}$ table $=\mathrm{df}-\mathrm{k}-1=1,657$.

Testing Criteria:

- Ho is accepted if $t$ count $<t$ table;

- Ho is rejected if $t$ count $>t$ table.

Table $3-\mathrm{t}$ test result

Coefficients $^{a}$

\begin{tabular}{|c|c|c|c|c|c|}
\hline \multirow[b]{2}{*}{ Model } & \multicolumn{2}{|c|}{ Unstandardized Coefficients } & Standardized Coefficients & \multirow[b]{2}{*}{$\mathrm{T}$} & \multirow[b]{2}{*}{ Sig. } \\
\hline & $\mathrm{B}$ & Std. Error & Beta & & \\
\hline (Constant) & $-3,894$ & 2,383 & & $-1,634$ &, 105 \\
\hline Informasi & 1,008 & ,198 & & 5,089 &, 000 \\
\hline Motif & ,438 & ,132 & & 3,311 & 001 \\
\hline
\end{tabular}

a. Dependent Variable: Participation.

Source Primary data was processed, 2020.

Based on the results of analysis, the t count of information is $5.089>1.657$, so Ho is rejected, meaning that there is a significant influence between information access and youth participation in developing educational tourism. Access to information is a youth activity in obtaining information through various means such as through counseling, mass media, electronic media and others related to activities carried out in educational tours. Transparency of information is the key in disseminating information, in this case the effort that must be made so that youth participation continues is the transparency of information between educational tourism managers and local youth who live around educational tours. According to Sumartias (2016) openness of information provides opportunities for people to participate so that information awareness and information disclosure is needed.

In the social motives t test results, $t$ count $3,311>1,657$ so that Ho is rejected. The meaning is that there is a significant influence between social motives on youth participation in the development of educational tourism in Kediri Regency. There are two sides to the social motive for participation, namely to obtain the status of a youth who will happily participate in an activity (tourism development) when his participation will have an impact on increasing his social status. On the negative side, youth will be forced to participate in an 
activity (development) for fear of being exposed to social sanctions (being left out or being ostracized by the community). The existence of a local wisdom that is still alive in the community is considered to be the dominant factor in influencing social motives in youth participation in developing educational tourism. According to Sartini (Panjaitan et al, 2014: 115), the existence of local wisdom functions in human resource development, cultural and scientific development, social meaning, for example communal integration ceremonies / relatives, ethical and moral meaning, etc.

The $\mathrm{F}$ test is used to collectively determine the influence of information access and social motives on participation. The $F$ test can be seen through the ANOVA results at significant numbers.

The hypothesis in the $\mathrm{F}$ test is as follows:

- Ho: There is no influence of access to information and social motives simultaneously on youth participation in the development of educational tourism in Kediri Regency;

- Ha: There is an influence of access to information and social motives simultaneously on youth participation in the development of educational tourism in Kediri Regency.

Table $4-F$ test results

ANOVA $^{\mathrm{a}}$
\begin{tabular}{|l|r|r|r|r|}
\hline Model & Sum of Squares & df & Mean Square & Sig. \\
\hline Regression & 1018,051 & 2 & 509,025 & 27,993 \\
Residual & 2127,541 & 117 &, $000^{\circ}$ \\
Total & 3145,592 & 119 & 18,184 & \\
\end{tabular}

a. Dependent Variable: Participation

b. Predictors: (Constant), Motive, Information.

Source Primary data was processed, 2020.

Based on the results of $F$ test analysis, the significant value is $0.000<0.05$. It means that $\mathrm{Ho}$ is rejected and $\mathrm{Ha}$ is accepted. There is a significant influence of information access and social motives simultaneously on youth participation in the development of educational tourism in Kediri Regency.

\section{CONCLUSION}

Based on discusion of the result in this test, the conclusions are Information Access and social motives partially affect youth participation in the development of educational tourism in Kediri Regency. The results of the $F$ test show a significant value $(0.000)<(0.05)$ meaning that simultaneously information access and social motives have a significant influence on youth participation in developing educational tourism in Kediri Regency.

\section{REFERENCES}

1. Badan Pusat Statistik. 2015. Statistik Migrasi Jawa Timur 2015.

2. Badan Pusat Statistik. 2015. Statistik daerah kabupaten kediri 2019.

3. Herlina Vivi. 2019. Panduan Praktis mengolah data kuesioner menggunakan SPSS. Jakarta: PT Elex Media Koputindo.

4. Mulyadi. 2009. Kepariwisataan and Perjalanan. Jakarta: PT Raja Grafindo Persada.

5. Panjaitan, dkk. (2014). Korelasi Kebudayaan \& Pendidikan. Yayasan Pustaka Obor.

6. R., N. R. (2014). Perancangan Wisata Edukasi Lingkungan Hidup. Malang: Universitas Brawijaya.

7. Septutyningsih, E and Setyaningrum E. 2019. Penelitian kuanttatif metode and alat analisis. Yogyakarta: Gosyen Publishing.

8. Sumartias,S. 2016. Dinamika Ketrebukaan Informasi Publik. Pusat Penelitian Badan Keahlian DPR RI and PT Balai Pustaka (Persero). Bandung: Balai Pustaka.

9. Soedarso, Nurif.M, Windiani. 2014. Potensi and Kendala Pengembangan Pariwisata Berbasis Kekeyaan Alam dengan Pendekatan Marketing Places di Kabupaten Bojoneoro. Jurnal Sosial Humaniora Vol 7 No 2. 